\title{
sciendo
}

CIVIL AND ENVIRONMENTAL ENGINEERING REPORTS

E-ISSN 2450-8594

CEER 2021; 31 (2): 0085-0104

DOI: 10.2478/ceer-2021-0021

Original Research Article

\section{KEY FINANCIAL INDICATORS BY THE SIZE OF THE CONSTRUCTION COMPANY - CZECH STUDY}

\author{
Eva VITKOVA ${ }^{1}$, Gabriela KOCOURKOVA ${ }^{1}$ \\ ${ }^{1}$ Brno University of Technology, Faculty of Civil Engineering
}

\begin{abstract}
Statistical data on the values of financial indicators in individual fields in the Czech Republic are provided by the Ministry of Industry and Trade. Updated values are issued quarterly. However, within the statistical samples, there are on average 34 companies focusing on construction. Moreover, no document specifies the size of the companies. Although the scientific literature provides basic financial rules, this research has confirmed that companies of different sizes show different values of financial indicators. For this reason, one of the aims of the research described in the article was to verify the hypothesis that companies of different sizes have different approaches to financial management and the other aims was to focus on correlating data on key financial indicators of individual sizes of companies with statistics provided by the Ministry of Industry and Trade. Basic methods of financial analysis (vertical analysis), selected ratios and basic statistical methods, which include correlation analysis, were used. The analysis was performed on 30 samples of construction companies, which were divided by size into small, medium and large. The outputs of the research will be further used for the followup research.
\end{abstract}

Keywords: equity; foreign capital; fixed assets; current assets; current liquidity, construction industry

\footnotetext{
${ }^{1}$ Corresponding author: Brno University of Technology, Faculty of Civil Engineering, e-mail: vitkova.e@fce.vutbr.cz
} 


\section{INTRODUCTION}

Each state publishes statistical data on the key financial indicators of companies within individual sectors. This statistical data can be taken as a trend in the corresponding field. For example, in the United States, this statistical data is provided by Bizminer [1], ValuSource [2] or IBISWorld [3] companies, which also provide forecasts of development of individual sectors. However, all the above-mentioned companies charge their outputs. The European Union publishes statistics from 28 countries on construction output [4], which are free of charge, however, financial statistic indicators are not published there, only the percentage representation of companies by size (micro, small, medium and large). In the Czech Republic, statistical data is not subject to charge. Entities such as the Czech Statistical Office [5] and the Ministry of Industry and Trade (MIT) [6] serve to publish the results of statistical surveys. The Czech Statistical Office focuses more on general data on inflation and unemployment, in individual sectors (construction, tourism, environment and others). The statistics published by the Ministry of Industry and Trade already deal with individual sectors classified according to NACE. Data on financial analysis indicators is published there. This research focuses only on the construction industry, which is published under the NACE classification sections F 41, 42, 43 (Construction of buildings, Civil engineering, Specialized construction activities). However, these statistics are not further subdivided by company size. That is, their data is completed in various ways. They are updated quarterly and basic economic data from the balance sheet and profit and loss statement and some ratios of the financial analysis is published in them.

The aim of the research described in the article was to analyse statistical data published by the Ministry of Industry and Trade in the Czech Republic and to find out which types of companies (according to company size) are closest to the outputs published by the Ministry of Industry and Trade and also to confirm the hypothesis that each company, according to its size, shows a different approach to financial management. This research question was supported by the publication of the fact that "Small and medium-sized enterprises (SMEs) are often referred to as the backbone of the European economy, providing a potential source for jobs and economic growth" [7].

\section{MATERIALS AND METHODS}

Financial indicators such as: property structure of companies, capital structure of companies and current liquidity were analysed and synthesized within the article. These indicators were selected because of the representation of the most basic indicators of financial management and financial rules. These indicators are often 
used in other types of research monitoring the financial performance of construction companies [8]. In the case of construction companies, their development and economic stability depends on winning contracts for construction works, which is the result of a well-planned bidding strategy [9] and reasonably calculated construction costs [10]. The company's activity are influenced by the environment of the construction investments [11], also materials [12] and energy requirements for buildings [13]. It is important to constantly monitor and optimize the share of external resources on the total capital with respect to the recommended values given by the golden rule $[14,15]$ for the management of the company in various stages of its development. Monitoring these indicators is important for all companies, as they are indicators of future possible development, financing $[16,17]$ and profit of the construction company [18] and they also serve for predicting the development of the entire state economy [19].

The above-mentioned financial indicators were determined using elementary analysis and a ratio indicator of financial analysis. Vertical analysis was used within the elemental analysis,

$$
I_{X}=\frac{\mathrm{RQ}}{\mathrm{BQ}} * 100
$$

Where:

IX ..... indicator of financial analysis ( $\mathrm{X}=$ fixed assets, current assets, equity, other sources) (\%)

RQ...... research quantity (thousands CZK)

BQ ...... basic quantity (thousands CZK)

The most important representative of financial management, namely current liquidity, was chosen within the ratio.

$$
C R=\frac{\mathrm{CA}}{\mathrm{CL}}
$$

Where:

CR ...... current ratio (-)

CA....... current assets (thousands CZK)

$\mathrm{CL}$........ current liabilities (thousands CZK)

The recommended range of ownership structure is not stated in any available scientific literature. The recommended range of capital structure is based on the golden balance rule and is stated as the ratio of equity on foreign capital as $50 \%$ : $50 \%$ [20]. Other authors consider at least $30 \%$ of total capital to be a very good share of equity [21]. 
The recommended range for current liquidity is stated as $1.5-2.5$ according to available sources [14].

In the Czech Republic, the size of the company is given by Section 1b of Act No. 563/1991 Coll., On Accounting [22], which lists the categories as micro, small, medium and large. These sizes are determined according to the amount of sales, assets and number of employees. This definition is based on EU Commission Recommendation 2003/361/EC (2003) of 6 May 2003, published by the Ministry of Industry and Trade and the Office for the Protection of Competition. As the data from the financial statements is largely not published for micro-companies, the data of only small, medium and large companies was used in the article.

The reference period was a 5-year period, which is usual for determining the development [23]. Due to the existence of complete statistical data only until 2018, the 2014 - 2018 period was taken into account.

According to a document published by the Ministry of Industry and Trade "Construction of the Czech Republic 2019" [24], the development of companies in construction industry has been constantly increasing since 2013, when there was an average year-on-year increase by $0.98 \%$ in $2013-2018$ period. The largest representation in these companies belongs to small companies, which in the 2013 - 2018 period was represented on average by $99.67 \%$ (median is $99.68 \%$ ), see Table 1.

Table 1. Percentage share of the companies in the construction industry by size [Authors' own work]

\begin{tabular}{ccccccc}
\hline Size/Year & $\mathbf{2 0 1 3}$ & $\mathbf{2 0 1 4}$ & $\mathbf{2 0 1 5}$ & $\mathbf{2 0 1 6}$ & $\mathbf{2 0 1 7}$ & $\mathbf{2 0 1 8}$ \\
\hline Large & 0.03 & 0.03 & 0.03 & 0.03 & 0.03 & 0.03 \\
Medium & 0.34 & 0.32 & 0.3 & 0.28 & 0.28 & 0.28 \\
Small & 99.63 & 99.65 & 99.66 & 99.69 & 99.69 & 99.69 \\
\hline
\end{tabular}

Small companies account for the largest share on total revenues of companies in the construction industry, which in the observed 2013 - 2018 period showed an average percentage representation of $57.86 \%$, see Table 2 .

Table 2. Percentage share of the companies in the construction industry according to revenues [Authors' own work]

\begin{tabular}{ccccccc}
\hline Unit & $\mathbf{2 0 1 3}$ & $\mathbf{2 0 1 4}$ & $\mathbf{2 0 1 5}$ & $\mathbf{2 0 1 6}$ & $\mathbf{2 0 1 7}$ & $\mathbf{2 0 1 8}$ \\
\hline Large & 22.55 & 23.52 & 24.6 & 20.47 & 19.8 & 18.53 \\
Medium & 22.4 & 21.24 & 20.9 & 20.4 & 19.65 & 18.8 \\
Small & 55.04 & 55.24 & 54.5 & 59.13 & 60.55 & 62.66 \\
\hline
\end{tabular}

It is clear from the tables stated above that the development of the construction industry is mostly influenced by small companies, which are largely represented 
by self-employed people. It should also be noted that the outputs listed in Table 2 above are not limited by the requirement to indicate the value of sales that would be performed on their own. Small companies function largely as suppliers for medium and large companies. Therefore, these revenues occur twice, once for a subcontractor in the form of a small company and for the second time for a construction contractor in the form of a medium or large company.

\section{RESULTS}

\subsection{Statistical data of the Ministry of Industry and Trade}

As already mentioned, the Ministry of Industry and Trade [11] publishes quarterly information on key financial indicators within individual sectors according to the NACE classification. Each sector fills the inputs for the statistics with a different number of samples. During the monitored 2014 - 2018 period, an average of 34 samples - companies - were considered in the construction sector (the number of samples for individual years is given in Table 3).

Table 3. Number of samples for statistical data [Authors' own work according to 6]

\begin{tabular}{cccccc}
\hline Year & $\mathbf{2 0 1 4}$ & $\mathbf{2 0 1 5}$ & $\mathbf{2 0 1 6}$ & $\mathbf{2 0 1 7}$ & $\mathbf{2 0 1 8}$ \\
\hline No. of samples & 29 & 42 & 40 & 36 & 25 \\
\hline
\end{tabular}

The percentage of the samples represented by individual sizes of companies in the construction sector is not mentioned anywhere.

The outputs of the key financial indicators for individual years are shown in Table 4.

Table 4. Statistical data of the Ministry of Industry and Trade [Authors' own work according to 6]

\begin{tabular}{lccccc}
\hline \multicolumn{1}{c}{ Year } & $\mathbf{2 0 1 4}$ & $\mathbf{2 0 1 5}$ & $\mathbf{2 0 1 6}$ & $\mathbf{2 0 1 7}$ & $\mathbf{2 0 1 8}$ \\
\hline Fixed Assets (\%) & 33.67 & 34.13 & 32.56 & 33.71 & 34.61 \\
Current Assets (\%) & 65.68 & 65.38 & 66.92 & 65.71 & 64.93 \\
Equity (\%) & 39.2 & 40.11 & 44.83 & 45.49 & 43.81 \\
Liabilities (\%) & 59.65 & 58.32 & 53.28 & 53.09 & 54.8 \\
Current Ratio & 1.71 & 1.71 & 1.99 & 2.04 & 1.88 \\
\hline
\end{tabular}

The data listed in Table 4 should be taken as an industry trend. However, it is nowhere shown which companies operating in the construction industry provided their data for statistical surveys according to their size. Therefore, the research task was focused on data collection as input for comparing statistical data of the 
Ministry of Industry and Trade with the research findings, which respect the division of outputs according to individual size categories of companies.

\subsection{Data collection for analysis}

Company size categories: small, medium and large, were taken into account for the analysis. The division into these categories is given by [22] and also by the Commission Recommendation 2003/361/EC (2003) of 6 May 2003, published by the Ministry of Industry and Trade and the Office for the Protection of competition. The conditions for inclusion into individual categories of companies are as follows:

- Small companies: total assets totalling at CZK 100,000,000 (EUR 3,824,092), annual total net turnover of CZK 200,000,000 (EUR 7,648,184), average number of employees 50; must not exceed at least 2 of the specified limits,

- Medium-sized companies: total assets totalling at CZK 500,000,000 (EUR 19,120,459), annual total net turnover CZK 1,000,000,000 (EUR 38,240,918), average number of employees 250; must not exceed at least 2 of the specified limits,

- Large companies: those that exceed at least 2 of the limits set out for mediumsized companies.

10 samples for each size of the company were considered as a part of the analysis, i.e. 30 samples were included in the total analysed number. Every company is obliged by Act No. 563/1991 Coll., On Accounting, to publish financial statements that contain financial statements (profit and loss statement and balance sheet). In this Act, the obligation to publish financial statements is imposed on those entities that are registered in the public register, i.e. typically on companies and, in some cases, also on natural persons engaged in business [22]. For each sample, the financial statements in the form of a profit and loss statement and balance sheet were downloaded from the justice.cz website [25]. Thus, a total of 300 items of data were worked on for the monitored 2014 - 2018 period. From them, 6 items were selected for the monitored period, i.e. for all samples for the monitored period it was 900 items. Individual indicators of financial analysis were determined from these items which were further compared with the statistical data of the Ministry of Industry and Trade.

\subsection{Outputs of the analysed data}

For each company, i.e. for 30 samples, the following items which were taken mainly from the balance sheet and the profit and loss statement, were analysed:

- quantity of fixed assets in thousands CZK,

- quantity of current assets in thousands CZK,

- quantity of equity in thousands CZK, 
- quantity of other sources in thousands CZK,

- quantity of short-term liabilities in thousands CZK.

The percentage share of these items was determined based on them using the method of vertical analysis (see Formula 2.1) and the current liquidity in individual 2014 - 2018 years was determined based on the ratio indicator (see Formula 2.2).

The determination of the asset structure was calculated on the basis of the formulae below.

$$
I_{F A}=\frac{\mathrm{Q}_{F A}}{\mathrm{Q}_{T A}} * 100
$$

Where:

IFA ......... indicator of fixed assets (\%)

QFA ........ quantity of fixed assets (thousands CZK)

QTA ......... quantity of total assets (thousands CZK)

$$
I_{C A}=\frac{\mathrm{Q}_{C A}}{\mathrm{Q}_{T A}} * 100
$$

Where:

ICA ......... indicator of current assets (\%)

QCA ........ quantity of current assets (thousands CZK)

QTA ........ quantity of total assets (thousands CZK)

The determination of the capital structure was calculated on the basis of the formulae below.

$$
I_{E}=\frac{\mathrm{Q}_{E}}{\mathrm{Q}_{T L}} * 100
$$

Where:

IE ........... indicator of equity (\%)

QE ........... quantity of equity (thousands CZK)

QTL ......... quantity of total liabilities (thousands CZK)

$$
I_{O S}=\frac{\mathrm{Q}_{O S}}{\mathrm{Q}_{T L}} * 100
$$

Where:

Ios .......... indicator of other sources (\%)

$\mathrm{QL}$............quantity of other sources (thousands CZK)

QTL ............quantity of total liabilities (thousands CZK)

Total outputs of analysed data for partial size category of companies were determined using the following formula.

$$
I y=\frac{\sum_{i=1}^{10} I_{X}}{10}
$$


Where:

Iy....... indicator of financial analysis per year (10 companies) $(\%)$

IX...... indicator of financial analysis $(\mathrm{X}=$ fixed assets, current assets, equity, other sources) (\%)

The total outputs of the analysis for all researched companies (30 samples) are shown in Table 5.

Table 5. Total outputs of analysed data of companies [Authors' own work]

\begin{tabular}{lccccc}
\hline \multicolumn{1}{c}{ Year } & $\mathbf{2 0 1 4}$ & $\mathbf{2 0 1 5}$ & $\mathbf{2 0 1 6}$ & $\mathbf{2 0 1 7}$ & $\mathbf{2 0 1 8}$ \\
\hline Fixed Assets (\%) & 25.69 & 25.16 & 23.91 & 24.04 & 26.03 \\
Current Assets (\%) & 69.89 & 70.75 & 72.16 & 71.96 & 70.14 \\
Equity (\%) & 36.89 & 39.08 & 39.02 & 39.45 & 39.65 \\
Other sources (\%) & 58.06 & 55.26 & 54.69 & 54.03 & 53.66 \\
Current Ratio & 2.52 & 2.57 & 2.17 & 1.96 & 2.08 \\
\hline
\end{tabular}

The average values of the analysed data of all 30 samples for the monitored period were determined, which show the following financial indicators:

- The ownership structure is in the ratio (FA:CA) - 25\%:71\% ${ }^{2}$,

- The capital structure is in the ratio (E:L) - 39\%:55\%

- Current liquidity amounts at 2.26.

If the overall outputs of the analysis (see Table 5) were compared with the data by the MIT (see Table 4), it can be stated that the average deviation of individual items in the monitored years ranges from -9 percentage points to +5.50 percentage points (see Table 6).

Table 6. Comparison of total outputs of analysed data of companies with statistical data of MIT [Authors' own work]

\begin{tabular}{lccccc}
\hline \multicolumn{1}{c}{ Year } & $\mathbf{2 0 1 4}$ & $\mathbf{2 0 1 5}$ & $\mathbf{2 0 1 6}$ & $\mathbf{2 0 1 7}$ & $\mathbf{2 0 1 8}$ \\
\hline Fixed Assets (\%) & -7.98 & -8.97 & -8.66 & -9.67 & -8.58 \\
Current Assets (\%) & 4.21 & 5.37 & 5.24 & 6.25 & 5.21 \\
Equity (\%) & -2.32 & -1.03 & -5.82 & -6.05 & -4.16 \\
Other sources (\%) & -1.59 & -3.05 & -1.41 & -0.94 & -1.14 \\
\hline
\end{tabular}

The outputs of the analysis for individual size categories of companies are shown in Tables 7, 8 and 9. The averages value for the monitored period and medium were always determined. Since the difference between these values was very small, average values were used for further calculations.

\footnotetext{
${ }^{2}$ For the property structure, the residual percentage falls within $100 \%$ of the accrual.

${ }^{3}$ For the capital structure, the residual percentage falls within $100 \%$ of the accrual.
} 
KEY FINANCIAL INDICATORS BY THE SIZE OF THE CONSTRUCTION COMPANY- 93 CHECH STUDY

Table 7. Outputs of the analysed data of large size companies [Authors' own work]

\begin{tabular}{lccccc}
\hline \multicolumn{1}{c}{ Year } & $\mathbf{2 0 1 4}$ & $\mathbf{2 0 1 5}$ & $\mathbf{2 0 1 6}$ & $\mathbf{2 0 1 7}$ & $\mathbf{2 0 1 8}$ \\
\hline Fixed Assets (\%) & 18.35 & 17.14 & 18.88 & 19.42 & 21.23 \\
Current Assets (\%) & 81.16 & 82.37 & 90.6 & 90.16 & 78.44 \\
Equity (\%) & 32.58 & 33.24 & 34.83 & 35.31 & 34.78 \\
Other sources (\%) & 65.93 & 65.22 & 64.25 & 63.25 & 64.31 \\
Current Ratio & 1.67 & 1.9 & 1.88 & 1.98 & 1.87 \\
\hline
\end{tabular}

The averages of the values of individual items for large companies were determined from the values in Table 7 as follows:

- The ownership structure is in the ratio (FA:CA) - 19\%: $81 \%$,

- The capital structure is in the ratio (E:L) - 34\%: 66\%,

- Current liquidity amounts at 1.86 .

If the outputs of the analysis for large size companies (see Table 7) are compared with data from the MIT (see Table 4), it can be stated that the average deviation for the individual items in the monitored years ranges from -15.00 percentage points to +15.00 . percentage points (see Table 8 ).

Table 8. Comparison of the outputs of the analysed data of large size companies with statistical data of MIT [Authors' own work]

\begin{tabular}{lccccc}
\hline \multicolumn{1}{c}{ Year } & $\mathbf{2 0 1 4}$ & $\mathbf{2 0 1 5}$ & $\mathbf{2 0 1 6}$ & $\mathbf{2 0 1 7}$ & $\mathbf{2 0 1 8}$ \\
\hline Fixed Assets (\%) & -15.32 & -17 & -13.68 & -14.29 & -13.38 \\
Current Assets (\%) & 14.58 & 16.99 & 13.68 & 14.45 & 13.51 \\
Equity (\%) & -6.62 & -6.87 & -10 & -10.18 & -9.03 \\
Other sources (\%) & 6.28 & 6.9 & 10.97 & 10.16 & 9.52 \\
\hline
\end{tabular}

Table 9. Outputs of the analysed data of medium-sized companies [Authors' own work]

\begin{tabular}{lccccc}
\hline \multicolumn{1}{c}{ Year } & $\mathbf{2 0 1 4}$ & $\mathbf{2 0 1 5}$ & $\mathbf{2 0 1 6}$ & $\mathbf{2 0 1 7}$ & $\mathbf{2 0 1 8}$ \\
\hline Fixed Assets (\%) & 39.07 & 38.19 & 32.89 & 31.34 & 36.16 \\
Current Assets (\%) & 60.26 & 61.11 & 66.48 & 67.8 & 63.19 \\
Equity (\%) & 48.43 & 50.75 & 49.51 & 47.17 & 44,49 \\
Other sources (\%) & 48.24 & 44.17 & 42.72 & 45 & 46.9 \\
Current Ratio & 4.09 & 4.17 & 3.13 & 2.58 & 2.51 \\
\hline
\end{tabular}

The averages of the values of individual items for the medium-sized companies were determined from the values in Table 9 as follows:

- The ownership structure is in the ratio (FA: CA) - 36\%: 64\%, 
- The capital structure is in the ratio (E: L) - 48\%: 45\% $\%^{4}$,

- Current liquidity amounts at 3.29.

If the outputs of our analysis for medium-sized companies are compared (see Table 9) with the data from the Ministry of Industry and Trade (see Table 4), it can be stated that the average deviation for individual items in the monitored years ranges from -10.00 percentage points to $+5,50$ percentage points (see Table 10).

Table 10. Comparison of the outputs of the analysed data of medium-sized companies with statistical data of the Ministry of Industry and Trade [Authors' own work]

\begin{tabular}{lccccc}
\hline \multicolumn{1}{c}{ Year } & $\mathbf{2 0 1 4}$ & $\mathbf{2 0 1 5}$ & $\mathbf{2 0 1 6}$ & $\mathbf{2 0 1 7}$ & $\mathbf{2 0 1 8}$ \\
\hline Fixed Assets (\%) & 5.4 & 4.06 & 0.33 & -2.37 & 1.55 \\
Current Assets (\%) & -5.42 & -4.27 & -0.44 & 2.08 & -1.75 \\
Equity (\%) & 9.22 & 10.64 & 4.67 & 1.68 & 0.68 \\
Other sources (\%) & -11.41 & -14.15 & -10.56 & -8.09 & -7.9 \\
\hline
\end{tabular}

Table 11. Outputs of the analysed data of small size companies [Authors' own work]

\begin{tabular}{lccccc}
\hline \multicolumn{1}{c}{ Year } & $\mathbf{2 0 1 4}$ & $\mathbf{2 0 1 5}$ & $\mathbf{2 0 1 6}$ & $\mathbf{2 0 1 7}$ & $\mathbf{2 0 1 8}$ \\
\hline Fixed Assets (\%) & 19.64 & 20.15 & 19.95 & 21.37 & 20.69 \\
Current Assets (\%) & 68.24 & 68.78 & 69.41 & 67.92 & 68.79 \\
Equity (\%) & 29.65 & 33.26 & 32.71 & 35.86 & 39.68 \\
Other sources (\%) & 60.01 & 56.41 & 57.09 & 53.84 & 49.77 \\
Current Ratio & 1.82 & 1.63 & 1.49 & 1.34 & 1.87 \\
\hline
\end{tabular}

The averages of the values of individual items for small companies were determined from the values in Table 1 as follows:

- The ownership structure is in the ratio (FA: CA) - 20\%: 67\%

- The capital structure is in the ratio (E: L) - 34\%: 55\%,

- Current liquidity amounts at 1.63 .

If the outputs of the analysis for small companies (see Table 11) are compared with data from the MIT (see Table 4), it can be stated that the average deviation of individual items in the monitored years ranges from -14.00 percentage points to +3.00 percentage points (see Table 12).

\footnotetext{
${ }^{4}$ In the case of the capital structure, the residual percentage falls within $100 \%$ of the accruals.

${ }^{5}$ In the case of the property structure, the residual percentage falls within $100 \%$ of the accrual.

${ }^{6}$ In the case of the capital structure, the residual percentage falls within $100 \%$ of the accruals.
} 
Table 12. Comparison of outputs of the analysed data of small size companies with statistical data of the Ministry of Industry and Trade [Authors' own work]

\begin{tabular}{lccccc}
\hline \multicolumn{1}{c}{ Year } & $\mathbf{2 0 1 4}$ & $\mathbf{2 0 1 5}$ & $\mathbf{2 0 1 6}$ & $\mathbf{2 0 1 7}$ & $\mathbf{2 0 1 8}$ \\
\hline Fixed Assets (\%) & -14.03 & -13.98 & -12.61 & -12.34 & -13.92 \\
Current Assets (\%) & 2.56 & 3.4 & 2.49 & 2.21 & 3.86 \\
Equity (\%) & -9.56 & -6.86 & -12.12 & -9.64 & -4.13 \\
Other sources (\%) & 0.36 & -1.91 & 3.82 & 0.75 & -5.03 \\
\hline
\end{tabular}

Two conclusions clearly result from the above-listed outputs:

1. A different financial management is applied depending on the size of the company.

2. For each size category of the company, an average deviation results from the published outputs of the MIT and it is not entirely clear which category of companies influences the statistical outputs of the MIT.

\subsection{Financial management of companies according to their size}

The above-listed analysis of companies shows that each company operates differently according to its size. The average values for the observed period were determined from the Tables 7, 9 and 11 (the median was not used due to very similar values of the determined averages) for each monitored financial variable. The average values of equity for individual sizes of companies and the average value of the trend in the construction industry, which was determined from statistics published by the Ministry of Industry and Trade, are shown in Figure 1.

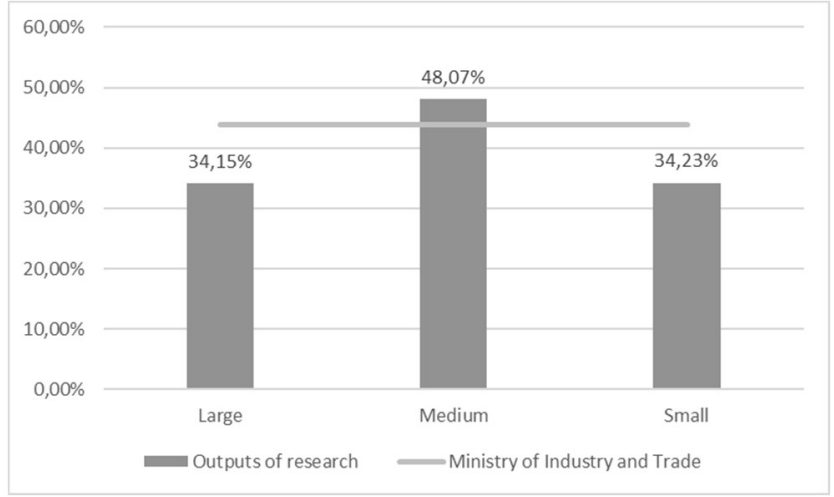

Fig. 1. Comparison of equity [Authors' own work]

Figure 1 shows that large and small companies manage their own capital at the same amount, at about $35 \%$, which is below the industry trend, which ranges around $43 \%$. Medium-sized companies are the most financially sound in terms of equity, with an average of $48 \%$, which almost reached the ideal financial management, where the ratio on equity and foreign capital is $50 \%: 50 \%$. 
The following figure shows the average values of foreign capital for individual sizes of companies and the trend in the construction industry.

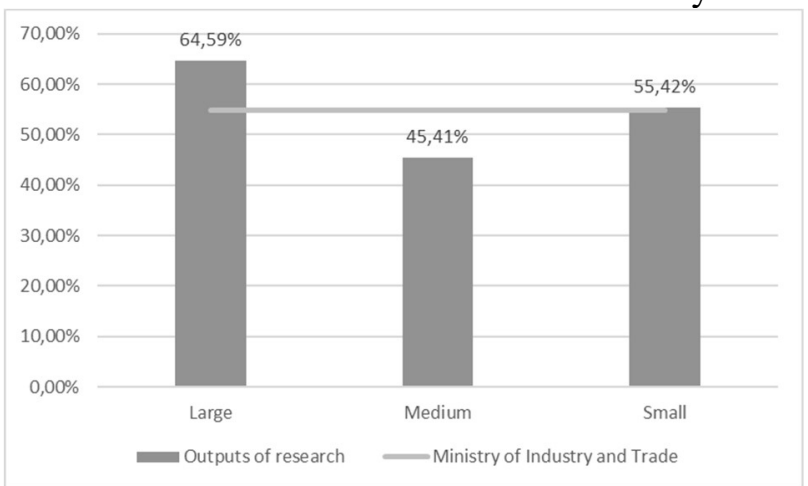

Fig. 2. Comparison of other sources [Authors' own work]

The values in Figure 2 clearly show that the ideal representation of foreign sources, i.e. $50 \%$ of the total capital was reached by small companies. Mediumsized companies manage foreign capital at an average of $45 \%$ and large companies have a share of foreign capital higher than the trend of the construction industry, which is on average at $56 \%$. Large companies have an average share of $65 \%$. For optimal financial management, further analysis of foreign capital is very important to determine whether it is capital borrowed from banking institutions, leasing companies and other entities or if it is a classic supplier-customer relationship, where the researched companies use so-called business loans to finance their contracts.

In this context, another examined indicator is important for the overall insight into financial management, namely the current liquidity. This indicator shows how is a company able to cover (repay) its short-term liabilities, which include mainly trade payables (classic supplier-customer relationship), payables towards the employees, payables towards social and health security, payables towards the state or liabilities towards banking institutions (loans with a maturity of up to 1 year). Figure 3 shows the average value of current liquidity for the period under research for individual categories of company sizes and the trend in the construction industry. 


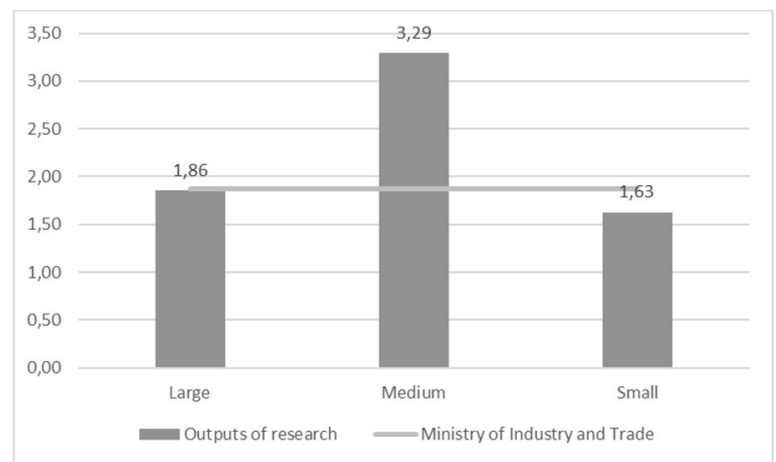

Fig. 3. Comparison of current ratio [Authors' own work]

Figure 3 shows that even though large companies use excessively foreign resources for their financing, they are able to repay their liabilities and are more liquid than the industry trend within normal liquidity (the average value is around 1.87). Small companies, on the other hand, have lower liquidity than the industry trend, but even though they can be described as liquid, because they are at the lower recommended limit between 1.5. Medium-sized companies, which manage foreign capital of less than $50 \%$, thus use foreign resources to a lesser extent for their financing, are over-financed in terms of liquidity. They hold more funds in current assets than necessary and at the same time they have a low level of shortterm liabilities. The upper recommended limit of current liquidity is around 2.5, medium-sized companies had an average value of current liquidity for the observed period of 4.84. For further comments, it would be necessary to analyse in detail the structure of current assets and short-term liabilities of medium-sized companies in order to define measures leading to more efficient allocation of allocated funds in current assets.

Following the above-listed comments, Figure 4 shows the average values of current assets according to individual sizes of companies and the trend of the construction industry.

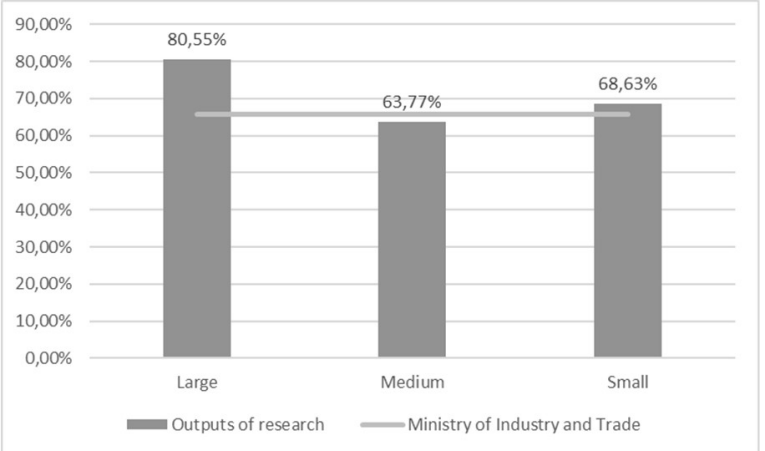

Fig. 4. Comparison of current assets [Authors' own work] 
Figure 4 shows that the average trend value in the construction industry is around $65 \%$ of current assets representation. Medium-sized companies and small companies fall close to this limit, with an average percentage of between $63-68 \%$. It is evident for large companies that they have a very high percentage of current assets, around $80 \%$. Following the values given above for current liquidity, it is clear that medium-sized companies have a very high share of funds in current assets and for small and large companies there is only the assumption that a large share of current assets is represented by short-term receivables, i.e. funds that are tied up in receivables from customers or waiting to be repaid, i.e. future funds. Further closer comments would require a deeper analysis of the structure of current assets.

Figure 5 shows the addition to $100 \%$ of the total assets as well as the average percentage of fixed assets of individual categories of companies and the trend in the construction industry. It is evident from the Figure 5 that the trend in the field ranges around $34 \%$ on average, which is close to the average values of mediumsized companies, which show a value of $36 \%$. Large and small companies both have an average percentage of around $20 \%$. This value can be explained for small companies by the fact that they do not allocate funds to fixed assets and therefore do not own them except for the essentials, they only borrow necessary assets. For large companies, there is the same assumption, but with the difference that they finance fixed assets primarily through leasing (operative), i.e. it is a lease of property and they are therefore not the owners of this property.

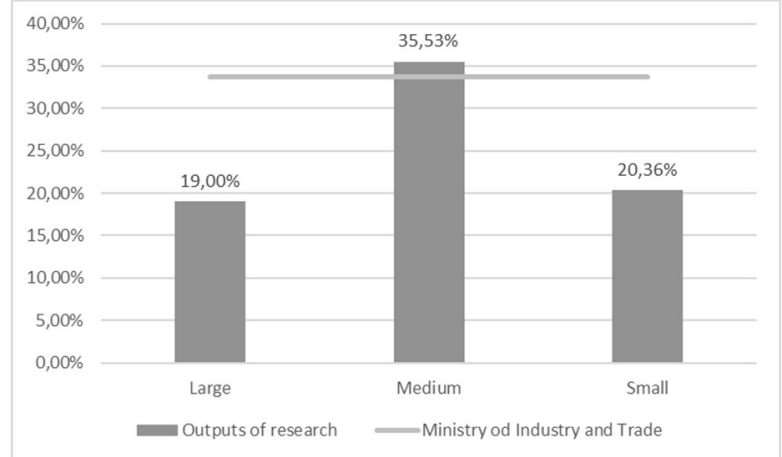

Fig. 5. Comparison of fixed assets [Authors' own work]

\subsection{Correlation between the analysed data and statistical data}

Another significant part of the research was devoted to the question of which category of company most influences the statistical outputs published by the Ministry of Industry and Trade. A correlation analysis was used for this research and it was found out on its basis which companies according to their size have the greatest influence on statistical data published by the Ministry of Industry and 
Trade. A linear dependence was tested between the individual values of selected indicators of the financial analysis of individual sizes of companies and the statistical data published by the Ministry of Industry and Trade. The degree of correlation was expressed using a correlation coefficient, the so-called Pearson correlation coefficient, which is the proportion of covariance of quantities and the product of their standard deviations. It is expressed by the following formula:

Where:

$$
r=\frac{\operatorname{cov}(X, Y)}{\sigma_{X} \cdot \sigma_{Y}}=\sum_{j}^{n} \sum_{i}^{n}\left(x_{i}-\bar{x}\right) \cdot\left(y_{j}-\bar{y}\right)
$$

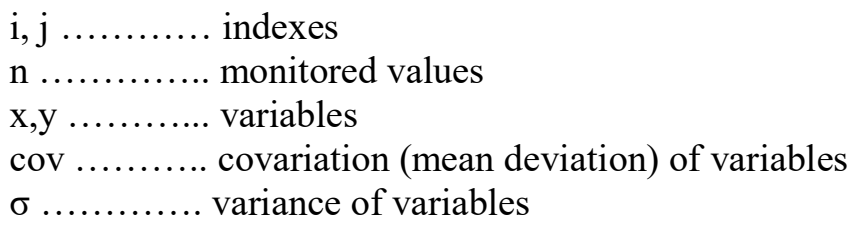

The correlation coefficient can take values from -1 to +1 , where negative values indicate an indirect dependence and positive values a direct dependence between variables. A value of zero indicates a non-existent (or undetected) connection.

The correlation was therefore performed for the following financial indicators:

- current ratio,

- equity,

- other sources,

- fixed assets,

- current assets.

The following tables show summarized values of individual financial indicators that were analysed, as well as the values published by the Ministry of Industry and Trade.

Table 13. Outputs of current ratio, analysed data and statistical data of companies [Authors' own work]

\begin{tabular}{lccccc}
\hline \multicolumn{1}{c}{ Year } & $\mathbf{2 0 1 4}$ & $\mathbf{2 0 1 5}$ & $\mathbf{2 0 1 6}$ & $\mathbf{2 0 1 7}$ & $\mathbf{2 0 1 8}$ \\
\hline Large & 1.67 & 1.9 & 1.88 & 1.98 & 1.87 \\
Medium & 4.09 & 4.17 & 3.13 & 2.58 & 2.51 \\
Small & 1.82 & 1.63 & 1.49 & 1.34 & 1.87 \\
MIT & 1.71 & 1.71 & 1.99 & 2.04 & 1.88 \\
\hline
\end{tabular}


Table 14. Outputs of equity in \%, analysed data and statistical data of companies [Authors' own work]

\begin{tabular}{lccccc}
\hline \multicolumn{1}{c}{ Year } & $\mathbf{2 0 1 4}$ & $\mathbf{2 0 1 5}$ & $\mathbf{2 0 1 6}$ & $\mathbf{2 0 1 7}$ & $\mathbf{2 0 1 8}$ \\
\hline Large & 32.58 & 33.24 & 34.83 & 35.31 & 34.78 \\
Medium & 48.43 & 50.75 & 49.51 & 47.17 & 44.49 \\
Small & 29.65 & 33.26 & 32.71 & 35.86 & 39.68 \\
MIT & 39.2 & 40.11 & 44.83 & 45.49 & 43.81 \\
\hline
\end{tabular}

Table 15. Outputs of other sources in $\%$, analysed data and statistical data of companies [Authors' own work]

\begin{tabular}{lccccc}
\hline \multicolumn{1}{c}{ Year } & $\mathbf{2 0 1 4}$ & $\mathbf{2 0 1 5}$ & $\mathbf{2 0 1 6}$ & $\mathbf{2 0 1 7}$ & $\mathbf{2 0 1 8}$ \\
\hline Large & 65.93 & 65.22 & 64.25 & 63.25 & 64.31 \\
Medium & 48.24 & 44.17 & 42.72 & 45 & 46.9 \\
Small & 60.01 & 56.41 & 57.09 & 53.84 & 49.77 \\
MIT & 59.65 & 58.32 & 53.28 & 53.09 & 54.8
\end{tabular}

Table 16. Outputs of fixed assets in \%, analysed data and statistical data of companies [Authors' own work]

\begin{tabular}{lccccc}
\hline \multicolumn{1}{c}{ Year } & $\mathbf{2 0 1 4}$ & $\mathbf{2 0 1 5}$ & $\mathbf{2 0 1 6}$ & $\mathbf{2 0 1 7}$ & $\mathbf{2 0 1 8}$ \\
\hline Large & 18.35 & 17.14 & 18.88 & 19.42 & 21.23 \\
Medium & 39.07 & 38.19 & 32.89 & 31.34 & 36.16 \\
Small & 19.64 & 20.15 & 19.95 & 21.37 & 20.69 \\
MIT & 33.67 & 34.13 & 32.56 & 33.71 & 34.61 \\
\hline
\end{tabular}

Table 17. Outputs of current assets in \%, analysed data and statistical data of companies [Authors' own work]

\begin{tabular}{lccccc}
\hline \multicolumn{1}{c}{ Year } & $\mathbf{2 0 1 4}$ & $\mathbf{2 0 1 5}$ & $\mathbf{2 0 1 6}$ & $\mathbf{2 0 1 7}$ & $\mathbf{2 0 1 8}$ \\
\hline Large & 81.16 & 82.37 & 90.6 & 90.16 & 78.44 \\
Medium & 60.26 & 61.11 & 66.48 & 67.8 & 63.19 \\
Small & 68.24 & 68.78 & 69.41 & 67.92 & 68.79 \\
MIT & 65.68 & 65.38 & 66.92 & 65.71 & 64.93 \\
\hline
\end{tabular}

Based on the above-stated Formula 9, the following correlation coefficients were determined for the individual financial indicators shown in Tables $13-17$. 
KEY FINANCIAL INDICATORS BY THE SIZE OF THE CONSTRUCTION COMPANY- 101 CHECH STUDY

Table 18. Correlation's coefficients [Authors' own work]

\begin{tabular}{lccccc}
\hline & Current ratio & Equity & Other source & $\begin{array}{c}\text { Fixed } \\
\text { assets }\end{array}$ & Current assets \\
\hline Large & 0.68 & 0.99 & 0.94 & 0.3 & 0.26 \\
Medium & -0.85 & -0.42 & 0.54 & 0.45 & 0.49 \\
Small & -0.69 & 0.6 & 0.56 & 0.34 & 0.46
\end{tabular}

Table 18 shows the resulting correlation coefficients. The results of this table show that large companies are the closest to the values published by the Ministry of Industry and Trade. If we took into account the score in the results of Table 18, while respecting the size of companies, where the best value of the correlation coefficient would be rated 1 (the value of the correlation coefficient should be close to +1 ) and the worst, on the contrary 3 (the value of the correlation coefficient should be close to -1), then the final output of the correlation analysis from all monitored financial indicators would be obtained (see Table 19).

Table 19. Outcomes of point evaluation [Authors' own work]

\begin{tabular}{lccccc}
\hline & $\begin{array}{c}\text { Current } \\
\text { ratio }\end{array}$ & Equity & Other source & Fixed assets & Current assets \\
\hline Large & 1 & 1 & 1 & 3 & 3 \\
Medium & 3 & 3 & 3 & 1 & 1 \\
Small & 2 & 2 & 2 & 2 & 2
\end{tabular}

Table 19 shows that the sum of the point evaluations within the sizes of companies is as follows:

- large size - 9 points,

- medium-sized - 11 points,

- $\quad$ small size -10 points.

It follows from the above-stated information that large companies correlate the most with statistical outputs within selected financial indicators published by the Ministry of Industry and Trade, followed by small and finally medium-sized companies.

\section{DISCUSSION}

The presented paper deals with the differences in the financial management of companies according to their size. No survey statistics, which are carried out and are not charged, reflect the size of the companies. Statistical surveys are largely completed with data in the given sector, without respecting the size categories of companies, and they are dealt with as a whole in this way. However, because size categories are observed in some business areas, such as an application for a bank 
loan, resp. the interest rate are influenced by the size of the company and its financial management, together with the application for financial support under subsidy programmes also differentiate between candidates according to their size, the research focused on economic data in terms of the company size. As mentioned in the introduction to this article, many foreign entities provide statistical data, however, they are not either sufficiently structured within their outputs, the outputs are generalised for the whole sector, or this data is charged. In the Czech Republic, statistical data is presented as a trend in the field, based on financial analyses presented by the Ministry of Industry and Trade. Therefore, a part of the research was focused on the comparison of the analysed data while respecting the size of companies with the statistical data published by the Ministry of Industry and Trade.

The outputs of this research will be used for further research within business approaches according to the size of companies, where individual business opportunities for individual sizes of company will be examined. Multi-criteria analysis will be used in further research in order to compare individual sizes.

\section{CONCLUSIONS}

The aim of the article was to analyse the statistical data published by the Ministry of Industry and Trade in the Czech Republic as well as to verify the hypothesis that different sizes of companies have different approaches to financial management. 30 samples were considered within the analysed data, resp. companies that de facto correspond to the average value of samples that complete the input data of the MIT statistical survey. These 30 samples were selected according to the given criteria so that they meet the conditions for individual sizes of companies, i.e. so that there were always 10 samples in each category. The synthesis and analysis of input data was performed and individual basic financial indicators, which are the main representatives of financial management, were determined on the basis of them. It was found out that large and small companies manage their assets, capital and liquidity almost identically, however, the medium-sized companies are the most financially sound.

It was pointed out to the companies that the most closely follow the trend of the industry, i.e. that the most influence the results of statistical surveys published by the Ministry of Industry and Trade by determining the value of the correlation coefficient for individual items (financial indicators). It was concluded that large companies and their financial indicators influence the statistical data most of all. 


\section{ACKNOWLEDGEMENTS}

This paper has been worked out under the project of the specific research at the Brno University of Technology no. FAST-S-21-7472 - Management of Economic Processes in Construction Engineering.

\section{REFERENCES}

1. Bizminer. Available online: https://www.bizminer.com (accessed on 1. 10. 2020).

2. Valuation Resources, LLC. Available online: https://valuationresources.com (accessed on 29.9. 2020).

3. IBISWorld. Available online: https://ibisworld.com (accessed on 2. 10. 2020).

4. European Commission website. Available online: http://ec.europa.eu/Eurostat/statistics-explained (accessed on 28. 9. 2020).

5. Czech statistical office. Available online: https://www.czso.cz (accessed on 20. 9. 2020).

6. Ministry of Industry and Trade. Available online: https://www.mpo.cz/cz/rozcestnik/analyticke-materialy-astatistiky/analyticke-materialy/ (accessed on 25. 9. 2020).

7. Eurostat Statistics Explained website. Available online: https://ec.europa.eu/eurostat/statisticsexplained/index.php?title=Archive:Small_and_mediumsized_enterprises\&oldid $=81989$ (accessed on 20. 9. 2020).

8. Shahzad Anjum, M and Abu Bakar AH 2015. Analysis of Firm Financial Performance Models in Construction Industry. Advances In Environmental Biology 9 (5), 110-113.

9. Lesniak, A 2015. Classification of the Bid/No Bid Criteria - Factor Analysis. Archives of Civil Engineering 61 (4), 79-90.

10. Juszczyk, M and Leśniak, A 2019. Modelling construction site cost index based on neural network ensembles. Symmetry 11(3), 411.

11. Zięba, Z, Dąbrowska, J, Marschalko, M, Pinto, J, Mrówczyńska, M, Leśniak, A and Kazak, JK (2020, December). Built Environment Challenges Due to Climate Change. In IOP Conference Series: Earth and Environmental Science (Vol. 609, No. 1, p. 012061). IOP Publishing.

12. Skrzypczak, I, Kokoszka, W, Buda-Ożóg, L, Kogut, J and Słowik, M 2017. Environmental aspects and renewable energy sources in the production of construction aggregate. In E3S Web of Conferences (Vol. 22, p. 00160). EDP Sciences. 
13. Sztubecka, M, Skiba, M, Mrówczyńska, M and Bazan-Krzywoszańska, A 2020. An Innovative Decision Support System to Improve the Energy Efficiency of Buildings in Urban Areas. Remote Sensing 12(2), 259.

14. Bellone, F et al. 2010. Financial Constraints and Firm Export Behaviour, World Economy 33(3), 347-373.

15. Calandro, J and Flynn, R 2007. On Financial Strategy. Business Strategies Series, 8(6), 409-417.

16. Ungureanu, M, Frasineanu C, Nedelut M and Ioanas, C 2013. The Use of The Financial Rates to Analyse and Interpret the Financial Statements. Online. Metalurgia International, 18(5), 248-251.

17. Gundes, S, Atakul, N and Buyukyoran, F 2019. Financial issues in construction companies: bibliometric analysis and trends. Canadian Journal of Civil Engineering, 46(6), 329-337.

18. Pordea, D, Delia, D and Dorel, M 2020. The Impact of Operating Cash Flow and Current Ratio on The Profitability in Construction Industry, Online. Studia Universitatis "Vasile Goldis" Arad. Seria Stiinte Economice, 30 (1), 22-32.

19. Chen, HL 2009. Model for predicting financial performance of development and construction corporations. (Author abstract)(Report). Journal of Construction Engineering and Management 135(11), 1190.

20. Kubíčková, D and Jindřichovská, I 2015. Finanční analýza a hodnocení finanční výkonnosti. C. H. Beck, Praque, Czech Republic.

21. Kramer, S 2010. Peter Kralicek, Florian Böhmdorfer, Günther Kralicek Kennzahlen für Geschäftsführer. Controlling \& Management 54(4), 281-281.

22. Law no. 563/1991 Coll., On accounting, (in Czech).

23. Mařík, M 2018. Metody oceňováni podniku: proces oceněni, základni metody a postupy, 4th ed., Ekopress, Praque, Czech Republic.

24. Ministry of Industry and Trade; Building Czech Republic 2019 (in Czech), Available online: https:/mpo.cz/assets/cz/stavebnictvi-asuroviny/informace-z-odvetvi/2019/11/Stavebnictvi-2019.pdf, Czech Republic.

25. Ministry of Justice, Available online: https://www. justice.cz (accessed on 15. 9. 2020). 